\title{
Prioritizing the effective factors for customers attraction: A case study of Sepah Bank
}

\author{
Azim Zarei ${ }^{\mathrm{a}}$, Mohammad Hemati ${ }^{\mathbf{b}^{*}}$ and Mahdiyeh Rafeeian ${ }^{\mathrm{b}}$
}

${ }^{a}$ Department of Economic \& management, Semnan University, Semnan, Iran

${ }^{b}$ Department of Industrial \& management, Semnan University, Semnan, Iran

\begin{tabular}{l}
\hline A R T I C L E I N F O \\
\hline Article history: \\
Received July 10, 2011 \\
Received in Revised form \\
October, 3, 2011 \\
Accepted 15 January 2012 \\
Available online \\
18 January 2012 \\
\hline Keywords: \\
Customer attraction \\
Customer veneration \\
Customer satisfaction \\
Kano model \\
AHP method
\end{tabular}
A B S T R A C T

\begin{abstract}
During the past few years, privatization has recently changed banking industry and there has been an increase competition in this industry. New banks try to present better services to absorb customers and traditional banks attempt to improve their services to retain their existing customers. In such environment and with limited amount of resources, there is a necessity to prioritize different influencing factors on the quality of the services. The proposed study of this paper presents a multi criteria decision making method along with Kano method to prioritize the most influencing factors of service quality. The proposed study of this paper is implemented for one of the oldest banks in Iran called Sepah. We have gathered different factors influencing customer satisfaction for all Sepah banks located in Semnan, Iran and using, analytical hierarchy process we provide a detailed ranking.
\end{abstract}

(c) 2012 Growing Science Ltd. All rights reserved.

\section{Introduction}

Now days, banks like other institutions act globally. According to technology development, there has been tremendous changes in banking industry, which creates the need to make changes in better serving customers. This could create the necessity to acquire advances in technology for attracting more financial resources and customers. Information technology plays an important role in banks' activities by lowering costs for presenting better services through the easy access services such as telephone banking or internet services (Popli \& Rao,2009; Alamgir \& Shamsuddoha, 2009; Cheolho, 2010). In such competitive environment, banks need to assess themselves based on what their customer think of them. Customer is the only source of evaluation and they determine their banks for their banking activities. In fact, customers are part of banks' asset and everything starts from customer and ends to customer. What is important in new marketing is cooperation and move in from of customer veneration (Saifuddin Khondaker, 2010; Martínez-Ruiz et al., 2010).

\footnotetext{
* Corresponding author.

E-mail addresses: mo928hem@yahoo.com (M. Hemmati)

(c) 2012 Growing Science Ltd. All rights reserved. 
Emotional and behavioral liability creates confidence in mutual relationships. Some values and equity between customers and clerks, may create an opportunity for customer retention. Increasing emotional and behavioral liability in a bank causes keeping and developing the organizations share in comparison environment (Menon, K., \& O'Connor, 2007; Kim et al., 2006; Dhananjoy, 2010). Private banks compared with state banks are more successful in customer relationship management (CRM) since they tend to use more creative techniques and strategies in speaking with customer and creating good relationship. These banks could catch more success by increasing the service quality for customers compared with state banks. Every cooperation with its customers could create organization development or it could face problems by not having a good reaction to customers, which could be a treat that causes organization destruction. Customer in banking industry may react differently based on products and services. Banks as deposit units or intervene between cashes, collect additive asset all cashes of depositors on one hand and offer to consumers on the other hand. So bank branches should pay enough attention to depositors and consumers.

Attracting and retaining a customer or, in other words, customer loyalty is one of principle factors of banks success. In fact, customer loyalty is one of the most important components of banking industry these days. Thinking about performing electronic banking and IT integration and its challenges in banking system causes technologies new chances and great revolution in banking part (Agrawal, 2008). If banks provide more different services for every customer it causes benefit to bank in short time and possibility of keeping customer in long-term increases. Not attention to current beneficial customers results to attracting them by other banks and returning them is very difficult. Customer satisfaction is one of vital and important factors in banking system and has direct and positive influence on customer loyalty. Today many researchers and service marketers attempt to improve loyalty in customers for keeping competitive benefit and banks, which offer some service satisfaction attraction and loyalty are less tangible in them.

All organizations and product and service units surely have some weaknesses by not paying enough attentions to their customers, which could create serious problem in long-term. So understanding these weaknesses and shortages and provide fast responses to customers' needs is important. We should not forget that unsatisfied customers are more effective than satisfied ones. Customers veneration, customer satisfaction and attraction, are principles organizations' objectives. When a customer faces an obstacle he/she tries to remove the issue by using the service of other bank. Service quality is an important factor in customer attraction, which provides customer satisfaction, keeping customers and loyalty between them. Satisfied customers advice others to use their own bank services. Safety and correctness in bank activities are important parts in bank system. The rate of deposit's profit is another important factor, which would help customer keep their deposit in banks. Of course, there is a discipline mechanism for strong and cautious supervision toward profit rates. Granting debt and preparing exchange is important factor for fast growth of bank. During recent decades, private banks gained a great share in this investment. Sepah bank is one of the oldest Iranian Bank established in 1926 with 3,883,950 Rials and now with more than 2000 branches could attract adrift assets.

In Islamic banking, deposits as principle sources of the bank have special importance. Because deposits affect on cash and cash risk, rate of debts and as a result on costs and operational incomes of the bank. So identifying the factors attracting deposit can increase the success in these cases (Chen \& Wang, 2010) and customer attraction guarantees dynamics and vitality of a bank. Identifying the position and environmental properties have very effective role. Therefore, in this research, the effective factors of attracting customers in Sepah bank, Semnan are recognized from clerks and customers points of view and then they are prioritized. According to the subject, the questions are:

1. What are the effective factors of attracting customers in Sepah bank in Semnan?

2. How classify these effective factors?

3. What is the importance and priority of each effective factor? 


\section{Theoretical Framework}

\subsection{Importance of customer}

Customer attraction is one of important issues in banking industry, which has a determinant role in assessment of banks and financial institutions from the rate of access to bank purposes and it is always one of principle worries of today managers. Therefore, banks and institutions consider the customer and take their ideas and wills in their own purposes and tasks, increase the quality of service surely attract more customers. Therefore, they should recognize the customer and take the customer veneration, which creates worthiness in customer and satisfies then in banking affairs.

So according to past research studies, interview with experts, giving answer sheet to experts, managers and customers is a primary method of a typical survey. Table 1 shows some of the recently completed survey associated with our study.

\subsection{Kano model}

In late of seventy decade, 20th century, Kano, as one of the most notable experts of science, planned a management quality model. Many of past concepts were one dimensional but in Kano, quality or quality properties of the products and service divided in three groups (Mihelis et al., 2001).In Kano, the relation of each properties of goods or services to customer satisfaction and the effect of each factor on satisfaction is stated. The following graph shows the Kano model.

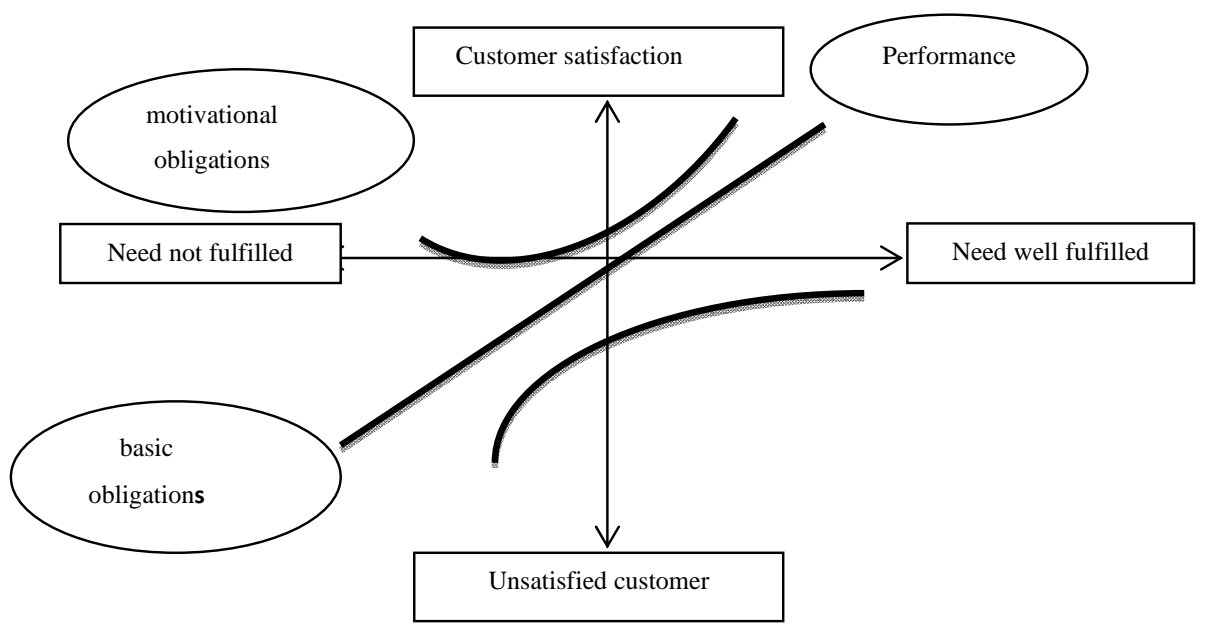

Fig. 1. Details of Kano model

\subsection{AHP method}

AHP $^{1}$ method was suggested by an Iraqi people named Saaty ${ }^{2}$ in 1970 . This method like a brain analyzes the problems (Selcen et al., 2009; Villalobs, 2000). The process of hierarchical analysis is one of $\mathrm{MADM}^{3}$ method that is identified for decision making and selection of a choice from different choices based on decision indexes. By documenting past researches and similarity of research subject to other articles in this case, we use models of Kano and AHP method.

\footnotetext{
${ }^{1}$ Analytic Hierarchy Process

${ }^{2}$ Thomas L.Saaty

${ }^{3}$ Multi Attribute Decision Making
} 


\section{Research method}

This article is a case study in Sepah bank, Semnan, which uses field and library method for collecting information. The instrument was a questionnaire and statistical society were clerks and customers of 8 branches of Sepah bank. For analyzing information Kano model and hierarchical analysis were used. In this article, final factors of the research from clerks and customers by two Kano questionnaires are divided into three groups of Basic, Performance and Motivational. The factors are compared using AHP technique. Sample method in this research is random and the sample volume for customers is from statistical society and for clerks is calculated by confined statistical society formula. In our survey, we have designed 200 questionnaires and distributed among 125 customers and 69 clerks. Cronbach Alpha has been calculated as 0.988 in the first level of survey, it was calculated to be 0.979 for Kano's customers' perspective and 0.948 in terms of Kano's clerks' perspective, respectively. These rates have confirmed the reliability of the system.

\subsection{Conceptual Model}

For a scientific research many actions are done, which should be surveyed and carefully performed. The following graph shows the performance frame of the research.

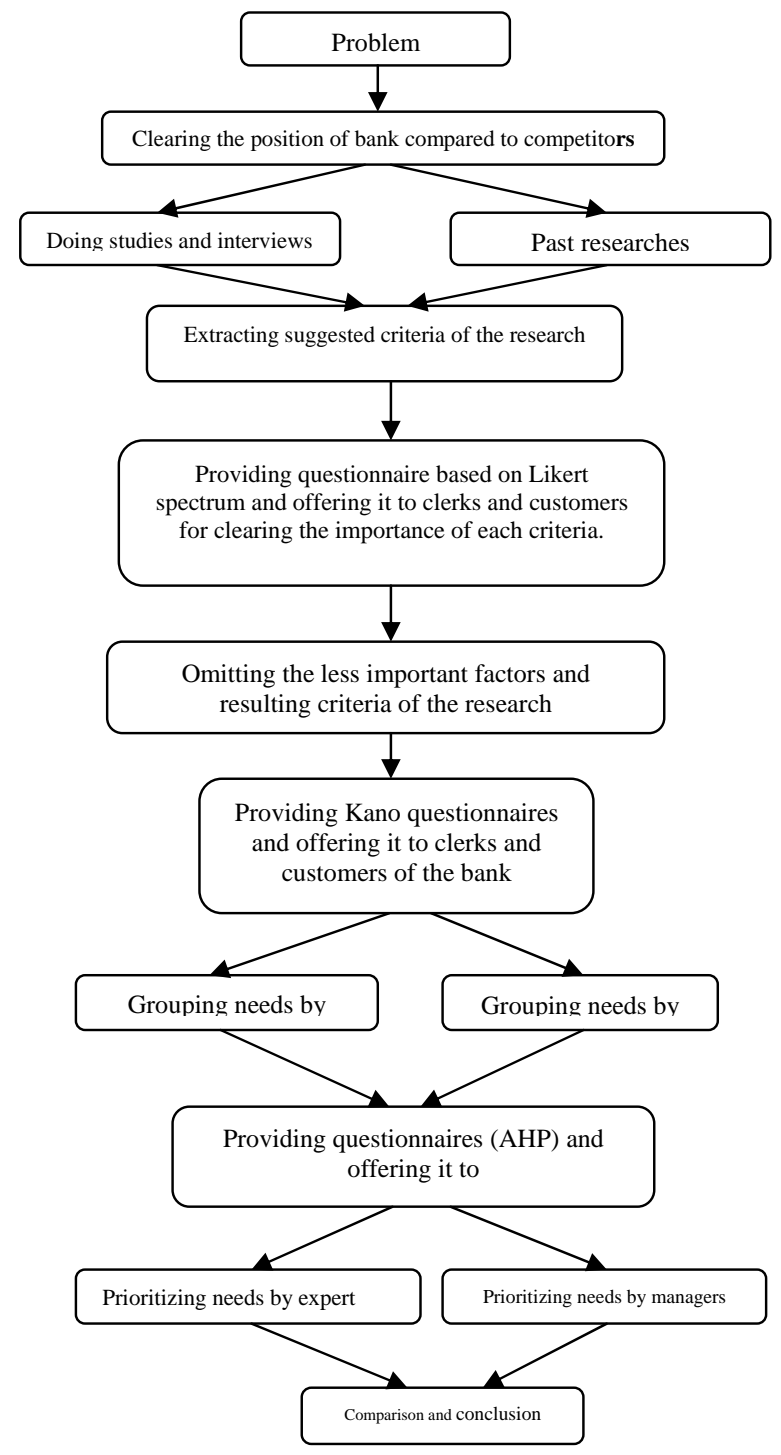

Fig. 2. Conceptual Model of research 
According to research process in Fig. 2 suggested factors are clerks behavior, diversity of bank services, rapidity in offering services, the rate of debts, branches place position, possibility of using electronic banking, the rate of debts, advertisement, innovation and particular services, banks fame, necessary time for bank services, the cost of bank services, prizes, the priority of debating to depositors, branches, tidiness, beneficial consultation to customers, increasing the number of branches, flexibility and surveying the complaints, the easiness of using bank services, safety in using bank services, service quality. These factors are collected using Kano model and they are prioritized using AHP method.

\section{Analysis and exploration of information}

\subsection{Categorizing the needs with Kano model}

Table 1 shows details of our Kano method.

Table 1

Categories compared to the needs of customers and employees view

\begin{tabular}{|c|c|c|c|c|c|c|c|c|c|c|c|c|c|}
\hline \multirow[t]{2}{*}{ Row } & \multirow[t]{2}{*}{ Factors } & \multicolumn{6}{|c|}{$\begin{array}{l}\text { Categorizing the needs from } \\
\text { managers and experts of Sepah bank } \\
\text { (50 persons) }\end{array}$} & \multicolumn{6}{|c|}{$\begin{array}{l}\text { Categorizing the needs from customers } \\
\text { of Sepah bank ( } 125 \text { persons) }\end{array}$} \\
\hline & & M & $\mathrm{O}$ & A & I & $\mathrm{R}$ & Most of & M & $\mathrm{O}$ & A & I & $\mathrm{R}$ & $\begin{array}{l}\text { Most } \\
\text { of }\end{array}$ \\
\hline 1 & Clerks manner way & 4 & 40 & 6 & & & $\mathrm{O}$ & 11 & 96 & 13 & 5 & & $\mathrm{O}$ \\
\hline 2 & Varity of bank services & 28 & 5 & 17 & & & M & 8 & 36 & 75 & 6 & & A \\
\hline 3 & The rapidity of giving services & 45 & 5 & & & & M & 103 & 19 & 3 & & & M \\
\hline 4 & Service quality & 34 & 16 & & & & M & 88 & 28 & 9 & & & M \\
\hline 5 & Place position of branches & & 13 & 31 & 6 & & A & 1 & 17 & 81 & 26 & & A \\
\hline 6 & Using the electronic facilities & 39 & 3 & 8 & & & M & 90 & 24 & 7 & 4 & & M \\
\hline 7 & $\begin{array}{l}\text { The rate of giving interest to } \\
\text { customers }\end{array}$ & 8 & 7 & 32 & 2 & 1 & A & 27 & 69 & 21 & 5 & 3 & $\mathrm{O}$ \\
\hline 8 & The rate of given facilities & 29 & 21 & & & & M & 89 & 33 & & 3 & & M \\
\hline 9 & Advertisement & 7 & 11 & 23 & 9 & & A & 4 & 3 & 95 & 23 & & A \\
\hline 10 & $\begin{array}{l}\text { Innovating and being particular } \\
\text { in service }\end{array}$ & 3 & 14 & 33 & & & A & 8 & 4 & 102 & 11 & & A \\
\hline 11 & Fame & & 4 & 36 & 10 & & $\mathrm{~A}$ & & 5 & 88 & 32 & & A \\
\hline 12 & $\begin{array}{l}\text { The enough time for receiving } \\
\text { bank services }\end{array}$ & 43 & 6 & 1 & & & M & 99 & 12 & 10 & 4 & & M \\
\hline 13 & $\begin{array}{l}\text { The cost of receiving bank } \\
\text { services }\end{array}$ & 35 & 12 & 3 & & & M & 77 & 39 & 3 & 6 & & M \\
\hline 14 & Awards & 3 & 13 & 24 & 6 & 4 & A & 18 & 21 & 78 & 7 & 1 & A \\
\hline 15 & $\begin{array}{l}\text { Preference of giving facilities to } \\
\text { depositors }\end{array}$ & 10 & 15 & 25 & & & A & 17 & 74 & 30 & 3 & 1 & $\mathrm{O}$ \\
\hline 16 & Tidiness of branches & & 11 & 34 & 5 & & A & 15 & 3 & 76 & 29 & 2 & A \\
\hline 17 & Consulting to customer & 7 & 29 & 14 & & & $\mathrm{O}$ & 20 & 32 & 69 & 4 & & A \\
\hline 18 & $\begin{array}{l}\text { Increasing the number of bank } \\
\text { branches }\end{array}$ & 11 & 9 & 26 & 4 & & A & 7 & 9 & 83 & 24 & 2 & A \\
\hline 19 & $\begin{array}{l}\text { Flexibility and consideration to } \\
\text { complaints }\end{array}$ & 32 & 14 & 4 & & & M & 31 & 86 & 7 & 1 & & $\mathrm{O}$ \\
\hline 20 & $\begin{array}{l}\text { Convenience in using of bank } \\
\text { services }\end{array}$ & 7 & 37 & 6 & & & $\mathrm{O}$ & 34 & 69 & 15 & 7 & & $\mathrm{O}$ \\
\hline 21 & $\begin{array}{l}\text { Security in using of bank } \\
\text { services }\end{array}$ & 48 & 2 & & & & M & 113 & 11 & & 1 & & $\mathrm{M}$ \\
\hline
\end{tabular}

In the following table each of the factors From the perspective of customers and bank employees are classified separately. 
Table 2

Categorize the needs in point of view of managers and bank experts

\begin{tabular}{|c|c|c|}
\hline \multicolumn{3}{|c|}{ Categorizing the needs in point of view of managers and experts of Sepah bank } \\
\hline Motivational needs (A) & Performance needs $(\mathrm{O})$ & Basic needs(M) \\
\hline Place position of branches & Clerks manner way & Rapidity in giving services \\
\hline Given interest rate to customer & Convenience in using of bank & Services quality \\
\hline Advertisement & Consulting to customer & Using electronic banking \\
\hline Innovation and being particular & & The rate of given facilities interest \\
\hline Fame & & $\begin{array}{l}\text { The enough time for receiving bank } \\
\text { services }\end{array}$ \\
\hline Awards & & The cost of receiving bank service \\
\hline $\begin{array}{l}\text { Priority of giving facilities to } \\
\text { customers }\end{array}$ & & $\begin{array}{l}\text { Flexibility and consideration to } \\
\text { complaints }\end{array}$ \\
\hline Tidiness of branches & & Security in using of bank services \\
\hline \multicolumn{3}{|l|}{ Increasing number of bank branches } \\
\hline Variety of bank services & & \\
\hline
\end{tabular}

Table 3

Categorize the needs in point of view of customers

\begin{tabular}{|c|c|c|}
\hline \multicolumn{3}{|c|}{ Categorizing the needs in point of view of customers of Sepah bank } \\
\hline Motivational needs (A) & Performance needs $(\mathrm{O})$ & Basic needs(M) \\
\hline Variety of bank service & Clerks manner way & Rapidity of giving service \\
\hline Place position of branches & Rate of given interest to customers & Services quality \\
\hline Advertisement & $\begin{array}{l}\text { Priority of giving facilities to } \\
\text { customers }\end{array}$ & Using electronic baking \\
\hline Innovation and particular service & $\begin{array}{l}\text { Flexibility and consideration to } \\
\text { complaint }\end{array}$ & Interest rate of given facilities \\
\hline Fame & Convenience in using bank services & $\begin{array}{l}\text { Enough time for receiving bank } \\
\text { service }\end{array}$ \\
\hline Awards & & Cost of receiving bank services \\
\hline Tidiness of branches & & Security in using bank services \\
\hline Consulting to customers & & \\
\hline $\begin{array}{l}\text { Increasing number of bank } \\
\text { branches }\end{array}$ & & \\
\hline
\end{tabular}

From comparison of customers' views and clerks' views, it was cleared that they are different in four cases. The rate of given interest to customers from managers view is motivational and from customers view is performance. The priority of giving debts to depositor from managers' view is motivation but from customers' view is performance. Offering beneficial consultations to customers from managers' point of view is performance but from customers' perspective is motivation.

Flexibility and surveying the complaints from managers' view is basic but from customers' view is performance. These differences are from not understanding of customers' needs in an institution, which could possibly reduce these differences and provide a guideline for banking purposes and competition with other banks and institution.

\subsection{Prioritizing the principle criteria}

The consistency ratios for AHP implementation in terms of customers and clerks are calculated as 0.0994 and 0.08780 , respectively, which validates the results. 
Table 4

Priority of main criteria of research based on AHP

\begin{tabular}{lllll}
\hline Priority of main criteria of research based on AHP & From customers & Rank & From clerks & Rank \\
\hline Basic needs & 0.6474 & 1 & 0.6408 & 1 \\
Performance needs & 0.2569 & 2 & 0.2608 & 2 \\
Motivational needs & 0.0957 & 3 & 0.0984 & 3 \\
\hline
\end{tabular}

\subsection{Prioritizing under the research criteria}

\subsubsection{Prioritizing under the criteria of basic needs}

The consistency ratios for AHP implementation in terms of customers and clerks are calculated as 0.0926 and 0.0332 , respectively, which validates the results.

\section{Table 5}

Priority sub factors on basic need based on AHP in point of view of customers and clerks

Priority sub factors on basic need based on AHP in Priority sub factors of basic need based on AHP in point of view of customers

\begin{tabular}{llllll}
\hline Factors & Weight & Rank & Factors & Weight & Rank \\
\hline Security & 0.4205 & 1 & Security & 0.3385 & 1 \\
Quality & 0.2258 & 2 & Quality & 0.2346 & 2 \\
Facility interest & 0.1573 & 3 & Electronic banking & 0.1466 & 3 \\
Electronic banking & 0.0916 & 4 & Rapidity & 0.1002 & 4 \\
Rapidity & 0.0511 & 5 & Time & 0.0793 & 5 \\
Time & 0.0295 & 6 & Cost & 0.044 & 6 \\
Cost & 0.0242 & 7 & Facility interest & 0.0348 & 7 \\
& & & Flexibility & 0.022 & 8 \\
\hline
\end{tabular}

\subsubsection{Priority under performance need sub factors}

The consistency ratios for AHP implementation in terms of customers and clerks are calculated as 0.0517 and 0.0213 , respectively, which validates the results.

\section{Table 6}

Priority of sub factors of performance needs based on AHP in point of view of customers and clerks Priority of sub factors of performance needs based on Priority of sub factors of performance needs based on AHP in point of view of customers AHP in point of view of clerks

\begin{tabular}{llllll}
\hline Factors & Weight & Rank & Factors & Weight & Rank \\
\hline Given interest & 0.4514 & 1 & Clerks manner way & 0.5949 & 1 \\
Priority of facilities giving & 0.2473 & 2 & Consulting & 0.2912 & 2 \\
Clerks manner way & 0.1548 & 3 & Convenience & 0.1139 & 3 \\
Flexibility & 0.0953 & 4 & & & \\
Convenience & 0.0512 & 5 & & & \\
\hline
\end{tabular}

\subsection{3. priory motivational need sub factors}

The consistency ratios for AHP implementation in terms of customers and clerks are calculated as 0.0879 and 0.0449 , respectively, which validates the results. 
Table 7

Priority of sub factors of motivational needs based on AHP in point of view of customers and clerks

Priority of sub factors of motivational needs based on Priority of sub factors of motivational needs based on

AHP in point of view of customers

\begin{tabular}{llllll}
\hline Factors & Weight & Rank & Factors & Weight & Rank \\
\hline innovations & 0.3173 & 1 & Given interest & 0.2276 & 1 \\
Varying of services & 0.2294 & 2 & innovations & 0.217 & 2 \\
Awards & 0.1597 & 3 & Varying of services & 0.1714 & 3 \\
Places position & 0.1005 & 4 & Priority of facilities giving & 0.124 & 4 \\
Consulting & 0.0712 & 5 & Advertisement & 0.0823 & 5 \\
Advertisement & 0.0519 & 6 & Awards & 0.0464 & 6 \\
Fame & 0.0299 & 7 & Places position & 0.0447 & 7 \\
Tidiness & 0.0233 & 8 & Fame & 0.0299 & 8 \\
Increasing branches & 0.0168 & 9 & Tidiness & 0.0239 & 9 \\
& & & Increasing branches & 0.0146 & 10 \\
\hline
\end{tabular}

Following table shows priory of all of sub factors each other in point of view of customers and clerks.

We can find out the difference between their opinions by comparing the results.

Table 8

Priority all of sub factors respect to each other in point of view of customers and managers by using AHP method

Priority all of sub factors respect to each other in Priority all of sub factors respect to each other in point of view of customers by using AHP method point of view of managers by using AHP method

\begin{tabular}{llllll}
\hline Criteria & Weight & Rank & Criteria & Weight & Rank \\
\hline Security & 0.2722 & 1 & Security & 0.2169 & 1 \\
Quality & 0.1462 & 2 & Clerks manner way & 0.1551 & 2 \\
Given interest & 0.116 & 3 & Quality & 0.1503 & 3 \\
Facility interest & 0.1018 & 4 & Electronic banking & 0.0939 & 4 \\
Priority of giving facilities & 0.0636 & 5 & Consulting & 0.0759 & 5 \\
Electronic banking & 0.0593 & 6 & Rapidity & 0.0642 & 6 \\
Clerks manner way & 0.0398 & 7 & Time & 0.0508 & 7 \\
Rapidity & 0.0331 & 8 & Convenience & 0.0297 & 8 \\
Innovation & 0.0304 & 9 & Cost & 0.0282 & 9 \\
Flexibility & 0.0245 & 10 & Given interest & 0.0224 & 10 \\
Varity of services & 0.022 & 11 & Facility interest & 0.0223 & 11 \\
Time & 0.0191 & 12 & Innovation & 0.0213 & 12 \\
Cost & 0.0157 & 13 & Varity of services & 0.0168 & 13 \\
Awards & 0.0153 & 14 & Flexibility & 0.0141 & 14 \\
Convenience & 0.0132 & 15 & Priority of giving facilities & 0.0122 & 15 \\
Place position & 0.0096 & 16 & Advertisement & 0.0081 & 16 \\
Consulting & 0.0068 & 17 & Awards & 0.0064 & 17 \\
Advertisement & 0.005 & 18 & Place position & 0.0044 & 18 \\
Fame & 0.0029 & 19 & Fame & 0.0029 & 19 \\
Tidiness & 0.0022 & 20 & Tidiness & 0.0023 & 20 \\
Increasing branches & 0.0016 & 21 & Increasing branches & 0.0014 & 21 \\
\hline
\end{tabular}

\section{Conclusion}

In this paper, we have presented a multi criteria decision making method along with Kano method to prioritize the most influencing factors of service quality. The proposed study of this paper has been implemented for one of the oldest banks in Iran called Sepah. We have gathered different factors influencing customer satisfaction for all Sepah banks located in Semnan, Iran and using, analytical hierarchy process we have provided a detailed ranking. Security has been considered as the first 
priority in both customers and managers' perspective. While quality of services is the second priority but Clerks' policies is the second priority in management's perspectives. Table 9 shows other priorities in both management and customers' perspectives.

\section{Table 9}

Comparison of the criteria in terms of customers and managers

\begin{tabular}{lll}
\hline Criteria & Managers rank & Customers rank \\
\hline Clerks manner way & 2 & 7 \\
Variety of bank service & 13 & 11 \\
The rapidity giving service & 6 & 8 \\
Service quality & 3 & 2 \\
Place position of branches & 18 & 16 \\
Using the electronic baking & 4 & 6 \\
The rate of giving interest of customer & 10 & 3 \\
The rate of given facilities & 11 & 4 \\
Publicity advertisement & 16 & 18 \\
Innovating and being particular in service & 12 & 9 \\
Reputation fame & 19 & 19 \\
The enough time for receiving bank services & 7 & 12 \\
The cost of receiving bank services & 9 & 13 \\
Awards & 17 & 14 \\
Preference of giving facilities to depositors & 15 & 5 \\
Tidiness of branches & 20 & 20 \\
Consulting to customers & 5 & 17 \\
Increasing the number of bank branches & 21 & 21 \\
Flexibility and consideration to complaints & 14 & 10 \\
Convenience in using of bank services & 8 & 15 \\
The security in using of bank services & 1 & 1 \\
\hline
\end{tabular}

\section{Acknowledgment}

The authors would like to acknowledgment the financial assistance of Islamic Azad University of Iran.

\section{References}

Alamgir, M., \& Shamsuddoha M. (2009). Loyality and satisfaction construct in retail banking - an empirical study on bank customers. Social Science Research Network.

Agrawal D. (2008). Building profitable customer relationships with CRM \&E- Governance in Banks. Social Science Research Network.

Cheolho, Y. (2010). Dept of business administration, Mokpo national university republic of Korea. Antecedents of customer satisfaction with online banking in China: The effects of experience.

Chen, Z., \& Wang, L. (2010). Personalized product configuration rules with dual formulations: A method to proactively leverage mass confusion. Expert Systems with Applications, 37(1), 383392.

Dhananjoy, D. (2010). Factors influencing customer satisfaction of two wheeler user at Agartala. Tripura, India .

Kim, W. G., Ma, X., \& Kim, D. J. (2006). Determinants of Chinese Hotel Customers' E-satisfaction and. Purchase Intentions, Tourism Management, 27(5), 890-900 
Martínez-Ruiz, M.P., Jiménez-Zarco, A.I., \& Izquierdo-Yusta, A. (2010). Customer satisfaction s key factors in spanish grocery stores :evidence from hypermarkets and supermarkets. Journal of Retailing and Consumer Services, 17 (4), 278-285.

Menon, K., \& O'Connor, A. (2007). "Building customers' affective commitment towards retail banks: The role of CRM in each 'moment of truth"', Journal of Financial Services Marketing 12 (2), 157.

Mihelis, G., Grigoroudis, E., Siskos, Y., Politis, Y., \& Malandrakis, Y. (2001). Customer satisfaction measurement in private bank sector. European Journal of operational Research, 130(2), 347-360.

Popli, G. S., \& Rao, D.N. (2009). Customer relationship management in Indian banks. Social Science Research Network.

Saifuddin Khondaker, M. (2010), Identifying customer satisfaction variables as a corporate governance mechanism for state owned banks in developing countries: A study of Bangladesh. Social Science Research Network.

Selcen, D., Aykac, O., Metin, A., Serkan, A., Ayse, Tansel Cetin (2009). Effects of service quality on customer satisfaction and customer loyalty: Marmara university hospital.

Villalobs, G. (2000). Web-application for the customer satisfaction. Journal of Bank Marketing, 20(4), 17. 